\title{
The Effect of Promotion on The Interests of Salic Paying Zakat, Infaq And Shadaqah in Amil Zakat Infaq And Shadaqah Jagad 'Alimussirry Institutions
}

\author{
L Arilia ${ }^{1}$, R Rahmatika ${ }^{2}$, Sholaita ${ }^{3}$ \\ ${ }^{1}$ Islamic Building School of Jagad Alimussirry Surabaya, Indonesia \\ ${ }^{2}$ Department of Biology, State University of Malang \\ ${ }^{3}$ Departmen of Management, State University of Surabaya \\ Email: linaarilia874@gmail.com
}

\begin{abstract}
Indonesia is the fourth most populous country in the world with a population of 265 million. There are $17 \mathrm{LAZ}$ at national level, $7 \mathrm{LAZ}$ at provincial level and $11 \mathrm{LAZ}$ at district level, the data is LAZ registered at baznas.go.id. The national zakat potential reaches Rp217 trillion expected to be able to overcome the problem of poverty found in Indonesia. Promotion factors become the most important means to attract and retain members. One of the promotional objectives of the Amil Zakat institution is to inform all types of products offered and try to attract new members. This study is a quasiexperimental study, researchers do not have the flexibility to manipulate subjects. The research design used in this study was "One Groups Pretest-Posttest Design". The effect of promotion on the interest in salik to pay zakat in the Amil Zakat institution Aladussirry before being given treatment in the form of brochures is still low or not significantly. The effect of promotion on the interest of salik to pay zakat in the Amil Zakat organization Jagad 'Alimussirry after being given treatment in the form of brochures was very high or significantly.
\end{abstract}

Keywords: Promotion, Amil zakat organization Jagad 'Alimussirry, pay zakat.

\section{INTRODUCTION}

Indonesia is the fourth most populous country in the world with a population of 265 million [1]. Whereas for Indonesian citizens who are Muslim according to Okefinance, 2018 are 216.66 million people [2]. Data obtained from baznas.go.id shows that there are $17 \mathrm{LAZ}$ at the national level, $7 \mathrm{LAZ}$ at the provincial level and $11 \mathrm{LAZ}$ at the district level, the data is LAZ registered at baznas.go.id [3]. Secretary General of the Ministry of Religion Nur Syam said that the potential of national zakat reached Rp 217 trillion [4]. The potential of ZIS is quite large, expected to be able to overcome the problem of poverty found in Indonesia.
Jagad 'Alimussirry Islamic Boarding School is one of the Islamic boarding schools in the city of Surabaya. In learning there must be the science of fiqhiyah which explains the importance of helping fellow believers by issuing or spending wealth in the way of Allah (doing alms and infaq). In this lodge, there are even a number of all santri who have carried out the process of meeting Allah or often called salik. This opportunity should be used by the Amil Zakat, Infaq and Sadaqah Jagad 'Alimussirry institutions in collecting donations from santri for those in need.

Promotion is the flow of one-way information created to direct someone or organization to actions that create exchange in marketing. Without a promotion, it does not 
guarantee that members can get to know the amil zakat institution. Therefore, promotion factors become the most important means to attract and retain members. One of the promotional objectives of the amil zakat institution is to inform all types of products offered and try to attract new members.

The amil zakat institution used in this research is the Amil Zakat, Infaq and Sadaqah Jagad 'Alimussirry institutions which actively hold social activities in most areas of the village of Jetis Kulon during Ramadan. Programs from this institution are still within the scope of Ketintang and Jetis in the Wonokromo area.

\section{METHOD}

This study is a quasi-experimental study, researchers do not have the flexibility to manipulate subjects. The research design used in this study was "One Groups Pretest-Posttest Design", namely the design of the study that had a pretest before being treated and posttest after being treated. This study aims to assess the effect of promotion on the interest in salik to pay ZIS at LAZIS JA or test hypotheses about the presence or absence of the effect of the treatment given.

This research will be conducted at the Jagad 'Alimussirry Islamic Boarding School located on J1. Jetis Agraria, Jl. Jetis Kulon VI 16 A and PTT VB 4-5. This research will be conducted from January 2019.

From the total population used in this study, there were 146 students at the Islamic Boarding School 'Alimussirry Islamic Boarding School. From the total population, the sample calculation is carried out as follows:

$$
20 \% \times 146=29.2 \text {. }
$$

In this study, the sample will be rounded to 30 .

The sampling technique in this study uses probability sampling techniques or probability sampling using simple random sampling.

If the instruments in this study are validity and reliability tests. While the hypothesis uses test $\mathrm{T}$ and $\mathrm{R}^{2}$ tests. While tenik analysis uses simple regression analysis.

\section{RESULT AND DISCUSSION}

\section{A. Role of Promotion at LAZIS JA}

According to Terence A. Shimp (2000) promotion has five functions / roles for an institution [5], the following are the five functions / roles:

\section{Informing (providing information)}

Promotion can make consumers aware of new products. Promotion displays the role of other valuable information, both for advertised brands and consumers by teaching new benefits that already exist. LAZIS JA has provided information on zakat, infaq and shadaqah through the Waliyul Adzim magazine.

\section{Persuading (Coax)}

A good promotional or advertising media can persuade customers to try the product or service offered. For the media currently covered in the brochure that became this study.

\section{Reminding (Remind)}

Advertising is currently aimed at influencing brand diversion by reminding consumers who have not bought a brand that has been available lately and contains beneficial attributes. In the brochure provided there are also invitations to do alms.

\section{Adding Value (add value)}

In promotion, there are three basic ways in which companies add value to their offerings, innovation, improving quality or changing consumer perceptions. This year, there will be innovations given by employees to LAZIS JA.

5. Assisting (assisting other efforts of the company)

Advertising can oversee the sales process of the company's products or institutions and provide a valuable 
introduction to the seller before making direct contact with the buyer. Therefore, in LAZIS JA there are brochures that can be read by prospective donors before asking more to the management or employees.

\section{B. Interest in Salik at LAZIS JA}

According to Winkel in Sari (2018) interest is the tendency rather settle in the subject field or feel attracted to certain things and get excited when bekecimpung in a bid ang terse but [6]. As was the case with Salik Islamic Boarding School 'Alimussirry, when asked if they knew the 'Alimussirry Amil Zakat Institute, they immediately said they did not know. But to pay zakat, infaq or alms in LAZIS JA they are still interested.

C. The role of promotion of paying zakat, infaq and sadaqah in increasing interest in salik pays zakat, infaq and shadaqah to LAZIS $J A$.

Before the promotion of giving brochures to the salik, the interest in salik to pay zakat was still low or not significantly. However, when given a promotion in the form of a brochure to the salik the results obtained were salik interested significantly or in full to pay zakat, infaq and shadaqah at LAZIS JA. This is what LAZIS JA had to start to continue to promote LAZIS JA products to santri and provide socialization to santri related to LAZIS JA. The more frequent administrators provide understanding to santri related to LAZIS JA, the more interested they will be even loyal to LAZIS JA.

As is the theory that was triggered by Kotler and Armstrong (2008) which states that promotion has an important role in causing people to become muzakki namely by means of sales promotions, advertisements and direct marketing tools that companies will use to persuasively communicate customer value and build customer relationships [7]. According to Hafidhuddin (2006), promotion for zakat institutions is a very important factor in socializing the obligation of zakat at once in the collection and utilization of zakat, infaq and shadaqah (ZIS) funds [8].

The research conducted by Fiqhyany and Ari (2014) with the title of the effect of integrated marketing communication on the intention of paying zakat, infaq and shadaqah funds in the Nurul Hayat Foundation Tuban Branch showed that marketing communication significantly affected the intention of paying zakat, infaq and shadaqah funds on Nurul Hayat Foundation, Tuban Branch [9].

\section{CONCLUSION}

1. The effect of promotion on the interest in salik to pay zakat in the Amil zakat institution Aladussirry before being given treatment in the form of brochures is still low or not significantly.

2. The effect of promotion on the interest of salik to pay zakat in the Amil zakat organization Jagad 'Alimussirry after being given treatment in the form of brochures was very high or significantly.

\section{REFERENCES}

[1] BPS. 2015. Gini Ratio March 2016. Obtained August 29 2018, from bps.go.id.

[2] Okezonefinance. 2018. Indonesia's Number 4 Population in the World, Who Is the Winner? Obtained 29 August 2018, accessed from https://economy.okezone.com/read/2018/0 7/21/320/1925559/indonesia-pendudukterbanyak-nomor-4-di-dunia-siapajuaranya.

[3] Baznas. 2016. 2017 Zakat Outlook , Jakarta: Strategic Study Center

[4] Kabar24.bisnis.com. 2018. Potential Zakat of Indonesian Communities. Obtained 29 August 2018, accessed from http://kabar24.bisnis.com/read/20180421/1 5/787071/pendapatan-zakat-ditarget-capairp8-triliun.

[5] Shimp, Terremce A. 2003. Promotional Advertising and Additional Aspects of 
Integrated Marketing Communication, 5th Edition Volume 1. Jakarta: Erlangga.

[6] Sari, Fitria Nurma. The Influence of the Level of Religiosity of Santri Darussalam Kediri Islamic Boarding School Against Interest in Saving in Islamic Banking. Thesis - Surabaya State University: 2018.

[7] Kotler, Philip and Gary Armstrong. 2008. Principles of Marketing. Edition Twelfth Volume 1. Jakarta Erlangga.

[8] Hafidhuddin, Didin. 2002. Zakat in the Modern Economy. Gema Insani: Jakarta.

[9] Fiqhyany, Mila Rahma and Ari Prasetyo. 2014. The Influence of Integrated Marketing Communication on Intention of Muzakki to Pay Alms Funds, Infaq and Sadaqah at Nurul Hayat Foundation, Tuban Branch. JIESTT. Vol. 1 No.11. 